\title{
The MIS 13 interglacial at Ceprano, Italy, in the context of Middle Pleistocene vegetation changes in southern Europe
}

Margari, V. ${ }^{\text {a }}$, Roucoux, K. ${ }^{\text {b }}$ Magri, D. ${ }^{c}$, Manzi, G. ${ }^{c}$ and Tzedakis, P.C. ${ }^{a}$

a Environmental Change Research Centre, Department of Geography, University College London, London, UK

b Department of Geography and Sustainable Development, University of St Andrews, Irvine Building, North Street, St Andrews, UK

c Department of Environmental Biology, Sapienza University of Rome, Piazzale Aldo Moro, 5, 00185, Roma, Italy

\begin{abstract}
Climatic and environmental changes of the Middle Pleistocene in Europe provide the context for an important phase in the evolution and dispersal of early hominins. Pollen records from terrestrial and marine sediment sequences reveal patterns not usually visible in palaeoenvironmental reconstructions from archaeological sites alone and show that hominin evolution took place against a background of marked environmental change as forests expanded and contracted in concert with global and regional climatic shifts. It is rare to find archaeological material in stratigraphically long and continuous palaeoenvironmental sequences, yet this is what is needed to enable particular phases of hominin evolution to be securely associated with climatic and environmental changes. At the well-known Middle Pleistocene archaeological site of Ceprano in Italy we have been able to produce a pollen record from the sedimentary unit directly below the stratum of the hominin remains. The new pollen data from Ceprano are presented here in full for the first time and provide a detailed picture of interglacial vegetation development during Marine Isotope Stage (MIS) 13. This evidence contributes significantly to our knowledge of the spatial heterogeneity of ecosystem responses to climatic change during this period and helps to further constrain the age of the hominin remains. New sites combining both archaeology and long, continuous high quality palaeoecological records would help clarify the relationship between hominin presence and palaeoclimatic and palaeoenvironmental conditions. In the meantime, better communication between the research communities can also go a long way to improving our understanding of the links between the two.
\end{abstract}

Keywords: Middle Pleistocene; pollen; southern Europe; vegetation; MIS 13, Ceprano; archaeology

\section{Introduction}

The Middle Pleistocene (773 to $126 \mathrm{ka}$; Head \& Gibbard, 2015) is an important period in the evolution of hominins and their dispersal across Africa and Eurasia. The earliest evidence for hominin presence in Europe is from the Early Pleistocene (c. 1.4 Ma, Italy and Spain, Arzarello et al., 2007; Martinez-Navarro et al., 1997; Oms et al., 2000, Carbonell et al., 2008; Toro-Moyano et al., 2013), but sites this old are scarce. From around $600 \mathrm{ka}$, there are significantly more sites preserving evidence for the longlived, persistent presence of hominin populations in Europe in the form of rich Acheulean assemblages, cut marks on bones, and relatively abundant occurrence of hominin skeletal remains generally attributed to Homo heidelbergensis (Rightmire, 1998; Hublin, 2009; Stringer, 2012; Moncel \& Schreve, 2016 and references therein). One plausible scenario based on the available evidence is that more or less persistent 
southern European populations of hominins expanded, likely more than once, into northern, western and central Europe. Both the pattern and timing of migrations, and the mechanisms and drivers of biological and cultural change in hominin populations, have frequently been linked in the literature to climatic change. However, a direct link is difficult to demonstrate (e.g. Dennell et al., 2011; Manzi et al., 2011; Moncel et al., 2018).

The Pleistocene is characterised by alternations between glacial periods (periods of increased global ice volume and low global average temperatures) and interglacial periods (periods with global ice volume and temperatures similar to the present day). A change in dominant periodicity from 40 -kyr to 100 -kyr is known as the Early-Middle Pleistocene Transition (EMPT) and occurred between $1.2 \mathrm{Ma}$ and $500 \mathrm{ka}$ (Head and Gibbard, 2015) or 1.2 Ma to 700 ka (Clark et al., 2006). The amplitude of the climatic cycles also increased significantly during the EMPT, with both glacials and interglacials becoming more intense after 430 Ma (Past Interglacials Working Group of PAGES, 2016; Tzedakis et al., 2009; EPICA Community Members 2004; Spratt and Lisiecki, 2016; Lang and Wolff, 2011). Thus, the Middle Pleistocene experienced not only pronounced cyclicity of climatic conditions, but also an overall trajectory of change towards greater climatic extremes.

The impact of these global scale climatic changes on the ground is recorded in a range of palaeoenvironmental proxy records preserved in lake, peat and marine sediment records. In Europe, there are several pollen records spanning parts of the Middle Pleistocene, but the only one which covers the entire period is the record from Tenaghi Philippon, in northeast Greece (Figures 1 and 5). It records the expansion and contraction of arboreal populations which took place in concert with global scale climatic oscillations, with both deciduous and Mediterranean taxa expanding during periods of warmth and increased wetness, and contracting during periods of cold and dry conditions (Tzedakis et al., 2006). All interglacial periods are characterised by high arboreal pollen (AP) values (Past Interglacials Working Group of PAGES, 2016), but their composition prior to MIS 16 was characterised by more diverse forest communities than today (Tzedakis et al., 2006).

This compositional change is not unique to Tenaghi Philipon, with a significant vegetational turnover being observed during the EMPT across Europe (Bertini, 2010; Magri et al. 2017). This occurred progressively and involved the local extirpation of subtropical taxa, as well an increase in the proportions of temperate (including Mediterranean) taxa during interglacials and steppe and arid-tolerant taxa during glacials, in comparison to the Early Pleistocene (Manzi et al., 2011; CombourieuNebout et al., 2015). Changes in mammalian faunas are also observed in southern Europe at this time including, in the last $400 \mathrm{ka}$, an increase in species richness and the appearance of the majority of modern taxa (Palombo et al., 2005; Palombo and Valli, 2005; Magri and Palombo, 2013). These lasting changes in floral and faunal composition were driven by the overall increasing aridity and severity of glaciations across the EMPT, as well as the overall larger amplitude of climate oscillations of the "100-kyr world".

Attempts to establish causal links between hominin development and the palaeoclimatic and palaeoenvironmental changes outlined above (e.g. Moncel et al., 
2018) are hampered by (a) a mismatch in the geographical scale represented by archaeological and palaeoclimatic/palaeoenvironmental records (e.g. cave sites versus lake basins) (Carrión et al., 2011), (b) the low preservation potential of palynological material in many archaeological sites and, equally, the low preservation potential of archaeological material in most good palynological sites (Moncel et al., 2018) and (c) the limitations of absolute dating and stratigraphic correlation, amplified by the often fragmentary nature of archaeological deposits (Carrión et al., 2011; Ashton and Lewis, 2012). Although taken together pollen records from southern Europe provide a temporally complete picture of patterns of vegetation development through the Middle Pleistocene, there remain many intervals for which local detail is lacking, thus, spatial heterogeneity (at the regional and local scale) is poorly understood. If we are to address questions about the drivers and controls of hominin evolution and dispersal during the Middle Pleistocene, we must improve our understanding of conditions on the ground, local to hominin sites before, during and after periods of occupation as evidenced by the archaeological record. This is a significant challenge, given the limitations above. Hence, new pollen records for any interval of the Middle Pleistocene are extremely valuable because of the local detail they contribute to the general scheme.

Here, we present a new pollen sequence from the Middle Pleistocene site of Ceprano, in Italy, and discuss from a palynological perspective the context of this site in terms of southern European environmental conditions. We extend the review beyond Italy to include all of southern Europe to provide a more complete understanding of the spatial response of vegetation to the climatic shifts of the Middle Pleistocene, since the presence of glacial refugia in southern Europe had significant implications for both the survival and evolution of plants and animals during the Quaternary (Hewitt, 2000; Tzedakis et al., 2002, 2013; Magri, 2010), it is possible that the spatial variability of environmental change also had an impact on the survival and evolution of hominin populations.

\section{Ceprano}

\subsection{Previous work}

Ceprano, located in the Latium region of central Italy (Fig. 2), represents an important site for assessing hominin habitation and heterogeneity in southern Europe. The Ceprano human calvarium (the upper portion of the skull without the lower jaw and the facial parts) was discovered in 1994 and was initially characterised as a representative of "late" Homo erectus with an assigned age of between 800 and $900 \mathrm{ka}$ (Ascenzi et al., 1996, 2000). Subsequent analysis of its morphological characteristics suggests that it represents an archaic variety of Homo heidelbergensis (Bruner and Manzi, 2007; Manzi, 2016, Di Vincenzo et al., 2017), which lived in the area between 430 and $385 \mathrm{ka}$ (this study and Manzi et al., 2010). The new chronology was the result of a systematic survey, which started in 2000 and looked into the geology, sedimentology, geochemistry, soil micromorphology, taphonomy, palynology and archaeology of the site. In addition to the human calvarium, the area has yielded a number of human artefacts belonging to Mode 1, Acheulean and Mousterian technocomplexes (Segre and Biddittu, 2009), while there is also a wealth of mammalian discoveries, including Palaeoloxodon antiquus, Stephanorhinus hemitoechus and Hippopotamus sp. (Ascenzi et al., 1996). The palynological record presented in this paper is based on the analysis of two sedimentary cores retrieved in 2005 in close 
spatial and stratigraphic proximity to the locations of the human calvarium and elephant discoveries (Fig. 2).

\subsection{Site description}

The study site is located $100 \mathrm{~km}$ southeast of Rome in the Latina Valley (c. $100 \mathrm{~m}$ altitude, Fig. 2), which hosted a large lacustrine basin (Lirino Lake) during the EarlyMiddle Pleistocene (Centamore et al., 2007). The site lies between the Mediterranean and Temperate Climatic regions (Di Pietro and Blasi, 1997; De Sillo et al., 2012), with Ceprano having a mean temperature of $6.6^{\circ} \mathrm{C}$ in winter and $23^{\circ} \mathrm{C}$ in summer, and mean annual precipitation of $1070 \mathrm{~mm}$. The Latina Valley is bordered by the Ausoni- Aurunci Mountains to the southwest and by the Simbuini- Ernici Mountains to the northeast. The physiographical heterogeneity of the region, reaching above $2000 \mathrm{~m}$ at its highest peaks, yields a variety of microclimates and of vegetational types. Currently, the bottom of the valley is largely occupied by cultivated fields. At higher elevations on both sides of the valley, mixed oak forests are found, characterised by alternating dominances of Quercus pubescens, Q. cerris, Ostrya carpinifolia, and Carpinus betulus, with various species of Acer, Tilia, and Fraxinus and a rich woody flora, including also a minor component of evergreen elements. Above 1000 m a.s.l., there are Fagus forests and open pastures (Attorre et al., 2006; Di Pietro and Blasi, 1997; De Sillo et al., 2012). In Ceprano, the close proximity to fresh water as well as the presence of a variety of vegetation types would have provided ample resources for early humans and made the site highly suitable for occupation.

\subsection{Materials and Methods}

To examine in depth the geological and sedimentological characteristics of the area, a trench was opened across the valley, along with the drilling of two sediment cores (Fig. 2). These cores were also used for the palynological, macro- and micro- morphological, geochemical and palaeomagnetic studies. Core C1 was located a few metres to the southeast of the road cut that yielded the human calvarium $\left(41^{\circ} 31^{\prime} 45.96^{\prime \prime} \mathrm{N}\right.$ $13^{\circ} 28^{\prime} 57.96 " \mathrm{E}, 48 \mathrm{~m}$ long with a gap at 38-39 m) and Core C2 was retrieved adjacent to the position of a fossilized elephant, $120 \mathrm{~m}$ northwest of C1 (41 31'48.37"N $13^{\circ} 28^{\prime} 56.29^{\prime \prime} \mathrm{E}, 36 \mathrm{~m}$ long with gaps at $11-15 \mathrm{~m}$ and $31-36 \mathrm{~m}$ ). Most of the pollen analysis was undertaken on core $\mathrm{C} 1$, as this included the stratigraphic level of the hominin and had a greater sediment recovery. C1 was subsampled every $10 \mathrm{~cm}$ for pollen analysis and standard chemical treatments, including treatment with $7 \% \mathrm{HCl}$, $10 \% \mathrm{NaOH}, 60 \% \mathrm{HF}$ and acetolysis (e.g. Berglund and Ralska-Jasiewiczowa, 1986), were used to remove the sediment matrix and concentrate pollen grains in the residue. A known amount of exotic 'spike' in the form of tablets containing spores of Lycopodium clavatum was added to each sample to enable estimation of fossil pollen concentration (Stockmarr, 1971).

Pollen grains were identified under x400 magnification and, when necessary, under x1000 magnification. Total pollen counts of vascular plants (excluding obligate aquatics and spores) were undertaken at a minimum of 300 grains per level. Pollen zones were identified using both numerical methods (Psimpoll programme, Bennett, 1993, 1998) and present knowledge of ecological preferences and importance of plant taxa. Pollen and spores were identified to the lowest possible taxonomic level using the pollen atlases of Reille (1992) and Moore et al. (1991), as well as reference slides at 
Sapienza University of Rome. Plant nomenclature follows Flora Europaea (Tutin et al., 1964-1980).

\subsection{Pollen analysis results}

The stratigraphy of core C1 is presented in detail in Manzi et al. (2010). In outline, the sequence is composed of four sedimentary units: consolidated marl deposits (Unit A: 48-38.8 m), limestone breccia (Unit B: 38.8-34.5 m), lacustrine sediments (Unit C: 34.5$14.7 \mathrm{~m}$ ) and muddy/sandy palustrine/fluvial deposits (Unit D: 14.7-0.3 m) (Fig. 3). All transitions between the sedimentary units are marked by stratigraphic discontinuities. Both the C1 and C2 cores are characterised by normal geomagnetic polarity and interpreted as pertaining to the Brunhes chron i.e. younger than $780 \mathrm{ka}$ (Muttoni et al., 2009). Based on both the geochemistry of the sediments and the scarcity vs. abundance of volcanic materials, as well as the regional chronostratigraphy of the ancient Lirino Lake, it is possible to constrain the deposition of Units D and C to between 580 and 360 ka (Manzi et al., 2010). Additional chronological control is provided by a leucitic tephra layer occurring just above the top of $\mathrm{C} 2$ and dated by K/Ar to $385 \pm 20$ ka (Ascenzi and Segre, 1997), which is consistent with the Ar/Ar date of $353 \pm 4$ ka obtained from Kfeldspars that were sampled above the clay layer of the human calvarium (Nomade et al., 2011).

Pollen preservation and abundance in the sediments was highly variable, with some intervals completely lacking palynomorphs and others characterised by highly degraded, and thus indeterminable, pollen grains (Fig. 3). Sediments associated with the human calvarium also proved to be palynologically sterile. Therefore, the palynological record from C1 spans the interval of good preservation, between 15 and $36 \mathrm{~m}$, corresponding mainly to the lacustrine sediments of Unit C. The results of pollen analysis are presented as percentages for selected taxa in Fig. 4.

The main arboreal pollen (AP) taxa represented in the sequence are Juniperus, Pinus, Alnus, Ulmus, deciduous and evergreen Quercus, Carpinus betulus, Corylus, Hedera and Abies covering a range of ecological preferences such as riparian, temperate, montane and, to a lesser extent, Mediterranean. Gramineae, Compositae Tubuliflorae, Artemisia, Compositae Liguliflorae, Chenopodiaceae, Caryophyllaceae and Cyperaceae comprise the main non-arboreal (NAP) taxa represented by the pollen. The pollen percentage diagram (Fig. 4) has been divided into three pollen assemblage zones:

(1) Zone C1-1 (37.4-27 m): Characterised by overall high AP values (around 70\%) with the exception of one sample close to the base of the sequence. Due to a change in character of the arboreal assemblage, this period has been divided into two subzones, with the lower part (C1-1a) showing a dominance of mesothermic taxa and the upper part (C1-1b) showing an expansion of montane forest taxa.

(2) Zone C1-2 (27-23.5 m): Dominated by NAP taxa (values are 47-84\%), with Pinus, Juniperus, deciduous Quercus and a few other mesothermic taxa present at low values.

(3) Zone C1-3 (23.5-14.7 m): Dominated by a diverse mesothermic arboreal pollen spectrum. This zone is subdivided into $\mathrm{C} 1-3 \mathrm{a}$ and $3 \mathrm{~b}$ to reflect the difference in proportions of arboreal taxa, with $\mathrm{C} 1-3 \mathrm{~b}$ showing lower AP values than $\mathrm{C} 1-3 \mathrm{a}$. This is due to an overall decrease in the abundance of mesothermic taxa, particularly deciduous Quercus, which are replaced by Gramineae.

\subsection{Palaeoenvironmental interpretation}


The pollen assemblages of zones C1-1 and C1-3 are dominated by high arboreal pollen percentages $(>70 \%)$, which suggest the continuous presence of closed-canopy forest. The main components of these forests are primarily mesothermic trees, shrubs and vines such as Carpinus betulus, Corylus, Ulmus, deciduous Quercus, Alnus and Hedera, with smaller contributions from Pinus and Juniperus. The floristic diversity of the arboreal vegetation is high, with Betula, Tilia, Fagus, Fraxinus, Acer, Celtis, Juglans, Viburnum, Abies and evergreen Quercus present in addition to those already mentioned. Such diverse arboreal pollen spectra suggest the coexistence of a mosaic of habitats and environmental conditions in the catchment area. Apart from the strongly hydrophilous Alnus, which would have grown on the lake shores, there are a number of other plants that tolerate waterlogging and/or high soil moisture, like Ulmus, Fraxinus, Pterocarya and Pteropsida. These taxa were also probably found in close proximity to the water body, while further away the forest was composed of other mesothermic taxa that require better drained soils, such as deciduous Quercus, Carpinus, Corylus, Castanea and Tilia. Drought-resistant taxa such as evergreen Quercus, Pinus and Juniperus could have expanded on south-facing slopes or generally drier areas, while montane taxa such as Abies and Fagus would have occupied the higher altitude areas. Of particular note is the presence of a suit of taxa no longer extant in southern Europe: Carya, Pterocarya, and Zelkova are present continuously, and Cedrus is present sporadically. Carya and Pterocarya are both moisture-demanding trees of the Juglandaceae family. In particular Pterocarya fraxinifolia, the species geographically closest to Europe nowadays, usually grows on topographically flat sites near open water, particularly in river valleys forming flooded forests often in association with Alnus glutinosa (Corrado and Magri, 2011; Magri et al., 2017).

The development of highly diverse and extensive forest communities in Ceprano requires temperate climatic conditions, associated with interglacial periods. The pattern of vegetational changes and the sequential expansion of different vegetation assemblages are consistent with $\mathrm{C} 1-1$ and $\mathrm{C} 1-3$ representing two different forest periods, separated by a period of open, herb dominated vegetation. The abundance of mesothermic taxa (especially Carpinus betulus) represented in zone C1-1a indicates that this interval corresponds to the temperate phase of an interglacial vegetation succession. This is followed by the expansion of Abies during subzone C1-1b, which is typical of the post-temperate phase of interglacials, characteristic of the period before the onset of the glacial steppe conditions in southern Europe (Follieri et al., 1988; Tzedakis, 2007). Indeed, a period dominated by herbaceous populations (Gramineae, Cyperaceae, Asteraceae, Chenopodiaceae, Ephedra and Caryophyllaceae) is depicted in the pollen assemblage of C1-2 and could indicate an interval of increased aridity and lower temperatures corresponding to a glacial period. The transition from glacial to interglacial conditions (the pre-temperate phase) is observed towards the end of C1-2 with successive increases of Pinus, Juniperus, deciduous Quercus and then Corylus. This is followed in zone C1-3 by the expansion of a diverse mesothermic forest with abundant Carpinus betulus and even a few Mediterranean taxa during the warm and dry conditions reflecting the temperate phase of interglacials. Although the end of the interglacial is missing, the reduction in arboreal forest cover represented in $\mathrm{C} 1-3 \mathrm{~b}$ suggests that the temperate phase was coming to an end.

\subsection{Biostratigraphy: contributions to the chronostratigraphy of Ceprano}


The sporadic finds of Cedrus, continuous presence of Carya and the absence of Tsuga provide important biostratigraphical information (Magri et al., 2017). Cedrus pollen is abundant in many Early Pleistocene Italian sites (Bertini, 2000; Ravazzi, 2003; Fusco, 2007; Joannin et al., 2007), while in the early Middle Pleistocene (MIS 21 and MIS 19) it is continuously present only in marine sediments from southern Italy (Bertini et al., 2015; Capraro et al., 2005). In all the other Middle Pleistocene Italian records Cedrus makes only sporadic appearances, which are interpreted to represent long-distance pollen transport from Africa (Magri et al., 2017). Thus, the sparse finds of Cedrus in the pollen record from Ceprano indicate a Middle Pleistocene age younger than MIS 19.

Tsuga is an important contributor to pollen assemblages in many Early Pleistocene Italian records (e.g. Ravazzi, 2003; Fusco, 2007; Ravazzi et al., 2005; Joannin et al., 2007), but it disappeared from northern Italy in the late Early Pleistocene (MIS 22; Muttoni et al., 2003). In Central Italy, Tsuga is still present at $>3 \%$ during MIS 17 at Torre Mucchia (Pieruccini et al., 2016) while only single pollen grains are recorded at Sessano during MIS 13 (Russo Ermolli et al., 2010). Nevertheless, its virtual absence from any other site of this age (Russo Ermolli, 1994; Lebreton, 2002) suggests that its distribution was rather patchy (Magri et al., 2017). The absence of Tsuga pollen at Ceprano further limits the age of the palynological record to younger than MIS 17.

Carya is extinct in Europe at present. Pollen percentages higher than $10 \%$ are found in Italy in Early Pleistocene deposits (e.g. Ravazzi, 2003; Joannin et al., 2007; Fusco, 2007). In northern Italy, Carya pollen has only been found in sediments older than MIS 22 (Muttoni et al., 2003), while in southern Italy it is still continuously present in pollen records equivalent to MIS 19 (although at values lower than 5\%, Capraro et al., 2005). In central Italy it is represented with values around 5\% during MIS 17 (Pieruccini et al., 2016). Then it is still frequently found during interglacial phases correlated with MIS 15 and 13 (Russo Ermolli, 1994; Russo Ermolli et al., 2010), after which it progressively declines and is last recorded during MIS 9 at Boiano (Orain et al., 2013). The frequent appearance (though low total abundance) of Carya in the pollen record from Ceprano therefore suggests that the sequence must be stratigraphically between MIS 17 and MIS 9.

Taken together, the pollen-based bio stratigraphy, the estimated age for the deposition of Unit C between (580- $360 \mathrm{ka}$, Manzi et al., 2010), and the leucitic tephra date from at the top of the sequence (385 $\pm 20 \mathrm{ka}$, Ascenzi and Segre, 1997) are consistent with the correlation of the two Ceprano forest phases to two different interglacial stages, perhaps MIS 15-13. This can be constrained further by a close analysis of the climatic patterns that characterise this interval. Both MIS 13 and 15 are better described as "interglacial complexes" than interglacials sensu stricto. MIS 15 has two substages, MIS $15 c$ and 15a, separated by a cool stage, MIS 15b; similarly, MIS 13 is subdivided into MIS 13c, 13b and 13a. Given the truncated nature of the vegetation successions recorded and the subdued population expansions of arboreal populations in both of the Ceprano forest phases, it is unlikely that they represent two separate and complete interglacials, suggesting their correlation with substages MIS 15c-15a or MIS 13c-13a. It is also unlikely that they represent the interval MIS 15a to 13c because the second interglacial phase (C1-3) appears to have larger and more variable tree populations than the first (C1-1) and thus appears warmer/wetter. This is not the pattern observed across MIS 15a to 13c in more complete palynological records where the stratigraphic 
position is uncontested (for example in Tenaghi Philippon, Tzedakis et al., 2006). Of the two remaining intervals in the marine isotope stratigraphy, the most likely candidate is MIS 13c-13a for two reasons: 1) the compositional similarity of the Ceprano phases with other records from southern Italy that are chronologically constrained by $\mathrm{Ar} / \mathrm{Ar}$ dates (Russo Ermolli et al., 2015), and 2) the expansion of Hedera recorded at Ceprano is also recorded during MIS 13 at Vallo di Diano but not found at any time in any other record from the Italian Peninsula.

The assignment of Unit C to MIS 13 along with the presence of an erosional surface between Units $C$ and D that is attributed to MIS 12 (the most extreme Pleistocene glacial), suggest that the timing of the deposition of the human calvarium in Unit D is within MIS 11 (i.e. between 425 and $385 \mathrm{ka}$ ) (Manzi et al., 2010). The poor pollen preservation of Unit $\mathrm{D}$, however, precludes a direct vegetation reconstruction at the time of human occupation. The absence of MIS 11 sites from Italy (apart from an incomplete representation at the site of Boiano in the Southern Appennines [Orain et al., 2012, 2013; Amato et al., 2014]), also complicates an assessment of the general vegetation character of that period. By drawing analogies with MIS 13 at Ceprano, therefore, we speculate that the landscape would have hosted a diverse and extensive woodland vegetation under relatively wet conditions during the hominin inhabitation in MIS 11. Indeed, MIS 11 is thought to have been a warmer and probably wetter interglacial than MIS 13, suggesting that the forest could have been even more extensive (e.g. higher tree line), but probably with fewer tree taxa, as the intervening MIS 12 would have likely led to further extinctions of Tertiary relicts in the region.

It is worth noting that during MIS $13 \mathrm{~b}$ tree populations shrank and the vegetation became more open with more abundant herbaceous taxa, suggesting cooling and drying of the climate. This demonstrates the sensitivity of the area to climatic change and shows the response to increased cold and aridity. Our record does not allow an assessment of the rate of change but other palaeorecords show that, such changes can occur across time periods on the order of hundreds of years and thus they could have a significant and noticeable impact on hominin life on the ground. The persistence of small areas of woodland during MIS 13b, suggest the presence of refugial areas nearby, where trees could survive during this colder and drier interval. The importance of such refugial areas in central Italy for both plant and mammal taxa has been emphasized by Manzi et al. (2011) who suggested that the existence of a diverse territory could have favoured the persistence and isolation of organisms, including hominins.

\section{Comparison with other MIS 13 records in central and southern Italy.}

In central and southern Italy MIS 13 is recorded in full at Sessano (700 m altitude; Russo Ermolli et al., 2010, 2015), Acerno (655 m altitude; Russo Ermolli, 2000; Munno et al., 2001; Petrosino et al., 2014a) and Vallo di Diano (450 m altitude; Russo Ermolli 1994; Russo Ermolli and Cheddadi, 1997), and in part at Mercure (550 m altitude; Petrosino et al., 2014b) and Boiano (490 m altitude; Orain et al., 2012, 2013; Amato et al., 2014).

In terms of vegetation, the full interglacial forest correlated with MIS 13 at Sessano is composed primarily of Abies, Fagus deciduous Quercus, Pinus, and Carpinus. Other taxa present are Ulmus, Tilia, Alnus, Corylus and Buxus as well as evergreen Quercus and Ericaceae. Small amounts of Zelkova pollen, sporadic pollen grains of Cedrus and Tsuga 
have also been identified (Russo Ermolli et al., 2010). During MIS 13 at Acerno deciduous Quercus, Pinus, Abies and Fagus dominate the vegetation, with smaller contributions from the montane taxa than in Sessano. Carpinus, Alnus, Ulmus, and Buxus, as well as some typical Meditteranean taxa (Quercus ilex, Olea, Pistacia and Phillyrea) and Ericaceae are also present. There is no Carya or Pterocarya and only sporadic grains of Zelkova and Cedrus have been recorded (Russo Ermolli, 2000). The composition of the MIS 13 forest community at Vallo di Diano is somewhat different since in addition to the dominant deciduous Quercus and Abies, there are significant contributions by Carpinus, Hedera, Ulmus and Zelkova, as well as evergreen Quercus, Pistacia and Ericaceae. Pinus shows very low values throughout this interglacial and Fagus is effectively absent. Carya and Cedrus are found sporadically (Russo Ermolli, 1994). At Boiano, only parts of MIS 13 are recorded. Core S1 has evidence of the early phase of the interglacial, when the vegetation was dominated by a mixed deciduous forest with Quercus, Carpinus, Ulmus, and Pinus as well as Abies and Picea, while core S2 shows evidence of the later interglacial vegetation stages when the deciduous forest has disappeared and is dominated by Abies, Picea and non arboreal taxa (Russo Ermolli et al., 2015). The most striking feature of the Boiano record is the significant presence of Picea, potentially located on the surrounding high relief. In terms of taxa which are now locally extinct, Carya and Zelkova are both represented in the pollen record. Finally, at Mercure it appears that only the initial phases of MIS 13 are recorded, as Abies and Fagus are represented in very low values. The forest vegetation is mixed temperate forest dominated by deciduous Quercus, Carpinus, Ulmus and Alnus, while there is also a small Mediterranean component. Only sporadic grains of Zelkova have been found (Petrosino et al., 2014b).

In a recent study, Russo Ermolli et al. (2015) used compositional data analysis to compare the vegetational characteristics of these five sites and concluded that despite strong similarities in their interglacial history, local environmental factors (including edaphic, topographic and climatic conditions) led to the development of distinctive forest communities in each site. The most distinct MIS 13 vegetation community emerging from their analysis is observed in Vallo di Diano, which is isolated from the rest of the sites in the biplot of relative variation because of its large amounts of Hedera and Zelkova pollen and the almost complete lack of Fagus (Russo Ermolli et al., 2015). When comparing the Ceprano sequence with the records outlined above, it is clear that the most similar pollen flora is found at Vallo di Diano. Both sites show the development of mixed mesothermic forests with significant contributions from a suite of taxa that benefit from, and/or tolerate, waterlogging (Alnus, Ulmus). Moreover, the significant presence of Hedera (reaching 10\% in the pollen spectrum) is unique among all the Italian MIS 13 records. The common European ivy, Hedera helix, is very sensitive to winter temperatures and water supply and such extensive populations suggest relatively mild winter conditions (above $-1.5{ }^{\circ} \mathrm{C}$ during the coldest month, Iversen, 1944) and high humidity levels (Metcalfe, 1958; Heuze et al., 2009). Another similarity is the low values of Fagus pollen at both sites (less than 3.2\% in Ceprano and only a few grains in Vallo di Diano), which has been attributed either to Fagus' low tolerance to water logging in the Appenines or to the restricted pollen source area of Vallo di Diano (it is thought to be restricted to the lowlands around the lake) (Russo Ermolli et al., 2015). Abies pollen, on the other hand, is present during the entire course of MIS 13 in Vallo di Diano, perhaps as it is more tolerant of waterlogging than Fagus, where it is suggested to have been a component of the lowland/plain vegetation (Russo Ermolli et 
al., 2015). In Ceprano, however, the Abies population showed a shorter expansion during what is believed to correspond to the post-temperate phase of the interglacial at the end of MIS 13a. Indeed, the short duration of the Abies expansion in Ceprano is not seen in any other MIS 13 site, where Abies is present throughout. This difference could be related to either the lower altitude of Ceprano and/or the greater distance from the Abies populations, which were located in the southern Appenines highest forest belt during the Middle Pleistocene (Russo Ermolli, 1994; Russo Ermolli et al., 2010). Another unique characteristic of the Ceprano vegetation assemblage is the significant presence of Corylus, which attains values of up to $47 \%$ of the pollen spectrum. The European hazel (Corylus avellana) is a highly adaptable pioneer species able to grow in both sun and shade and has widespread distribution. It commonly grows on lowland soils as an understorey shrub, often at the margin or within mesophilous forests. In Central Italy, Corylus was an important component of the vegetation during the Holocene at Valle di Castiglione (values c. 30\%, Follieri et al., 1988), Lagaccione (c. 30\%, Magri, 1999) and Monticchio (c. 20\%; Watts et al., 1999), while in northern Italy most early Holocene sites show values exceeding 30\% (Magri et al., 2015). In the Middle Pleistocene, it is found in abundance (up to 40\%) during MIS 5e at Azzano Decimo in northern Italy (Pini et al., 2009), while in Valle di Castiglione it is present during the interglacials prior to MIS 5e but with lower values $(<10 \%)$. At the Simbruini Mountains, Corylus is currently found in association with Carpinus betulus in narrow valleys characterised by mesic and humid microclimatic conditions (Attorre et al. 2006; De Sillo et al., 2012). These associations are usually in contact with Quercus cerris woodlands. Therefore, it is reasonable to suggest that the high percentages of Corylus in the Ceprano sequence represent populations living in a rather humid mesophilous forest together with Carpinus and deciduous Quercus.

Finally, the continuous presence of Carya, Pterocarya, and Zelkova in Ceprano confirms the existence of favorable pockets for the survival of these trees in the Latina valley and the adjacent mountain ranges. However, when comparing Ceprano with the other MIS 13 records from Central Italy, it is obvious that different taxa survived at different numbers in each site. This highlights the great degree of variability and complexity that characterised the terrestrial ecosystems at that time (Manzi et al., 2011; Magri and Palombo, 2013; Magri et al., 2017) as a result of physical (climate, topography) and/or historical (refuge location/ composition) factors (Russo Ermolli et al., 2015).

\section{The wider context of the Ceprano Interglacial: Middle Pleistocene vegetation in southern Europe}

Given the fragmentary nature of the Ceprano pollen sequence it is difficult to compare the environmental conditions that prevailed during MIS 13 (and MIS 11) with the remaining of the Middle Pleistocene and assess if they were more suitable or not for human inhabitation. Moreover, it is widely accepted that hominin populations were more or less consistently present in Europe during the last 600 ka (Manzi et al., 2011). This implies that human occupation could potentially occur during a continuum of climate and vegetation states ranging from full glacial to full interglacial. The following section provides a review of the Middle Pleistocene southern European vegetation in an attempt to identify potential patterns within the region.

\subsection{Italy}


Information on the Middle Pleistocene vegetation of the Italian peninsula is available from a number of sequences (Follieri et al., 1988; 1989, Magri et al., 2017; CombourieuNebout et al., 2015; Magri and Palombo, 2013; Bertini, 2010). Vallo di Diano spans the interval from MIS 16 to 12 and shows two periods of arboreal expansions composed primarily of deciduous Quercus. Despite similar total AP values, MIS 13 appears slightly warmer than MIS 15 as it is characterised by more Mediterranean taxa and Carpinus betulus, more continuous presence of Ulmus and Zelkova, as well as less Pinus and Abies (Russo Ermolli 1996; Russo Ermolli and Cheddadi, 1997). During both glacials, Pinus and a few other trees are still present while Gramineae, Compositae and Chenopodiaceae are rather abundant. Sessano covers part of MIS 15 to 12 (Russo Ermolli et al., 2010, 2015). Both MIS 15 and 13 are characterised by similar mixed deciduous forests composed mainly by deciduous Quercus and Carpinus betulus, and to a lesser extent a mixture of mesophilous (Ulmus, Zelkova, Tilia, Hedera and Buxus). However, in MIS 15 there is a reduced presence of Abies and Fagus, suggesting slightly warmer and drier conditions. During the glacial phases, Pinus is expanding along with herbaceous and steppic taxa (Gramineae, Artemisia, Chenopodiaceae and Compositae).

The pollen record from Boiano (Orain et al., 2012, 2013; Amato et al., 2014) covers the period from MIS 13 to MIS 9, with a short gap at MIS 10. Compared to the other records in the region, it is characterised by a significant presence of Picea, recorded together with Abies in all the forest periods. A distinctive character of MIS 11 is the expansion of Zelkova in a floristically rich mixed forest dominated by Abies and Picea. During MIS 9 the last occurrences of Carya and a significant expansion of Fagus are recorded in a forest dominated by deciduous Quercus, again with abundant Picea and Abies.

Later on in the Middle Pleistocene, after MIS 11, forest composition in Central Italy became much more recognizably modern. MIS 9 is partly recorded in the more or less stratigraphically continuous pollen record from Valle di Castiglione (44 m altitude, MIS 9a to present, Follieri et al., 1988, 1989). Here, an increase in both deciduous and evergreen Quercus, as well as Corylus, Ulmus, Carpinus betulus, Fagus, Juniperus and Pinus characterises MIS 9a (Tzedakis et al., 1997). The ensuing interglacial complex (MIS 7) is floristically more diverse with forests composed of Carpinus betulus, Fagus, deciduous and evergreen Quercus, Corylus, Ulmus, Tilia and Abies, reflecting the altitudinal zonation of the forest under warm and wet conditions. The highest arboreal pollen percentages (90\% excluding Pinus) are observed during MIS 7 (Fig. 5). Due to the presence of an interval of low pollen concentration and a core gap, only portions of MIS 8 and 6 are represented showing significant forest contractions (AP values are close to zero, excluding Pinus). Such low percentages are also observed during the stadial phases of MIS 7 (Follieri et al., 1988, 1989).

\subsection{Balkans}

The longest pollen record spanning continuously the last $1.35 \mathrm{Ma}$ from Southern Europe is from Tenaghi Philippon, in northeast Greece (Fig. 1) (Wijmstra, 1969; Wijmstra and Smit 1976; Van der Wiel and Wijmstra 1987a, b; Wijmstra et al., 1990; Mommersteeg et al., 1995; Tzedakis et al., 2006). Although the original publications are lacking some taxonomical detail (Quercus types are grouped together and Oleaceae includes Fraxinus) it provides invaluable information by allowing the direct comparison of vegetation during different periods. All interglacial and interstadial periods are characterised by significant AP values (almost 99\% in MIS 11) with, 
however, slightly reduced values (by c. 10\%) during MIS 17 and MIS 19 (Fig. 5). The diversity of all the forested phases is high with a number of deciduous, Mediterranean and montane taxa (Quercus, Zelkova, Pterocarya, Castanea, Pistacia, Juglans, Acer, Corylus, Tilia, Fagus, Carpinus betulus, Ulmus, Vitis, Pistacia, Abies) being present. The most floristically diverse interglacials occur prior to the Middle Pleistocene (i.e. before MIS 22-24). Most of the remaining relict taxa became extinct during MIS 16, after which a more 'modern' type of vegetation with higher numbers of Quercus, Carpinus betulus, Ostrya and Vitis becomes established (Tzedakis et al., 2006). An increase in the abundance of evergreen oak (Quercus coccifera/ilex) around the same time has been attributed to a shift towards a more Mediterranean/drier type of climate (Van der Wiel and Wijmstra, 1987a, b). During the glacial periods associated with these long-term changes in species composition, and also in MIS 12, there were especially significant declines in AP values to close to zero.

Further information on the late Middle Pleistocene vegetation is available from the Ioannina lacustrine sequence in northwest Greece (c. $400 \mathrm{~m}$ altitude). The published record from the stratigraphically more complete core I-284 extends from the present to the beginning of MIS 7e (c. $245 \mathrm{ka}$ ) (Tzedakis et al., 2002, 2003, 2004a; Lawson et al., 2004; Roucoux et al., 2008, 2011). Similar to Tenaghi Philippon, the Ioannina record shows the expansion and contraction of deciduous, Mediterranean and montane tree populations during interglacial/interstadial and glacial/stadial periods, respectively. Expanding forests (reaching similar values of up to $90 \%$ AP in both MIS 9 and MIS 7) were floristically diverse (including deciduous Quercus, Ulmus, Carpinus betulus, Olea, Pistacia, Fraxinus ornus, Fagus, Abies, Betula, Juniperus, and Pinus) and followed typical southern European successional patterns. As tree populations contracted during glacial and stadial periods herbaceous/steppe formations expanded. However, even during the strongest glacial periods there is a background component of temperate trees suggesting their survival in local refugia as a result of the relative topographic variability and high moisture availability (Bennett et al., 1991; Tzedakis et al., 1997).

Further north, the record from Lake Ohrid, located between Albania and FYROM, provides more information on the character of vegetation of the last $500 \mathrm{ka}(693 \mathrm{~m}$ altitude; Sadori et al., 2016). All interglacial and interstadial periods are characterised by expansions of altitudinal forest belts, with MIS 13 and MIS 11 having high values of montane taxa (Abies, Betula and Picea), while MIS 9 shows an increase in deciduous trees (such as deciduous Quercus, Carpinus betulus and Corylus). MIS 7 is quite variable with both montane and deciduous taxa. Both MIS 11 and MIS 9 appear cooler and drier than MIS 7 as suggested by the increased Picea and decreased Abies percentages. Glacial and stadial periods are dominated by grasslands, with MIS 12 being wetter than the rest based on the higher Pinus values. At Ohrid, most temperate tree taxa show a continuous presence suggesting that the region has also been a refugium for temperate trees (Sadori et al., 2016). The presence of pollen of several rare tree taxa during MIS 11 (Kousis et al., 2018) deserves special attention, as it support the notion that forest diversity at Lake Ohrid was higher during this interglacial than during the Holocene. These rare elements include Tertiary relics that still thrive on the Balkan Peninsula today (Picea omorika), and taxa that are currently extinct from the region (Carya, Cedrus, Parrotia, Pterocarya, Tsuga, and Zelkova). In particular, compared to the Italian Peninsula, later extirpations are recorded for Parrotia and Tsuga. 


\subsection{France}

Moving to the west, pollen records of Middle Pleistocene vegetation are available from the Massif Central in France from the Velay maars (between 1000 and $1200 \mathrm{~m}$ altitude, Reille et al., 2000) and the Alleret maar (c. 650 m altitude, Pastre et al., 2007; Nomade et al., 2010; Degeai et al., 2013). In Alleret, both MIS 15 and 17 are characterised by similar expansions of mixed deciduous forest (mainly deciduous Quercus and Carpinus betulus) followed by increases in montane taxa (Picea and Abies). A number of Tertiary taxa (including Tsuga, Cathaya, Pterocarya, Zelkova and Nyssa) are recorded during MIS 17, with however a noticeable reduction in diversity during MIS 15, which could be related to the harsh conditions during the intervening MIS 16 (Pastre et al., 2007; Degeai et al., 2013).

The Velay maars sequence, spanning the last $450 \mathrm{ka}$, is a composite sequence of cores from Lac du Bouchet, Ribains and Praclaux. It shows that all interglacial periods are characterised by high arboreal pollen percentages (more than $85 \%$ excluding Pinus, Fig. 5), but with differences in their composition and successional patterns (Reille and de Beaulieu, 1995; Reille et al., 1998, 2000). The most complete vegetation succession is observed during MIS 9e, Carpinus betulus is practically absent during MIS 11 and attains its highest values during MIS 7. Taxus is absent during MIS 7e, but present during MIS 9e, while Abies is dominant during MIS 11 and rare during MIS 7e (Reille and de Beaulieu, 1995). With the exception of the very low values $(<1 \%)$ of Pterocarya during MIS 11, the Tertiary taxa that were recorded in Alleret are missing. During all glacial and stadial periods there is a significant increase in the amounts of steppic taxa and Gramineae, as well as sporadic expansions of Pinus. Since most of the mesothermic taxa disappeared completely, the landscape was characterised as grassland with occasional Pinus forest (however, the local presence of this taxon has been questioned; Reille et al., 2000).

\subsection{Iberian Peninsula}

For Spain and Portugal there are currently no continuous continental pollen sequences covering the last $800 \mathrm{ka}$, while the few fragmentary sequences have very low resolution and uncertain chronological context (González-Sampériz et al., 2010). However, there is an emerging wealth of information from the analysis of marine sequences located off the coast of the Iberian Peninsula (Fig. 1). In southwest Iberia the Middle Pleistocene is represented in cores, MD01-2443 and MD01-2444, which span the period between MIS 6 and early MIS 11 (the transition from MIS 12 to 11 is missing; Fig. 5) (Tzedakis et al., 2004b; Roucoux et al., 2006; Tzedakis, 2010; Margari et al., 2010, 2014). Additional evidence for MIS 11 and 19 come from the adjacent core U1385, although the early part of MIS 11 is believed to be only partially represented due to either condensed sedimentation or a hiatus (Sánchez Goñi et al., 2016a, b). All interglacial periods are characterised by the expansion of deciduous, Mediterranean, and montane taxa with varying intensities. The strongest expansion is observed during MIS 11c (Tzedakis, 2010), with temperate pollen values reaching 60\%, while increases up to $45 \%$ are observed during MIS 19, MIS 9e as well as during all of the three warm phases of MIS 7 (maximum tree pollen values excluding Pinus on the Portuguese Margin sequences are usually lower than in land sequences, due to the continued presence of herbaceous taxa, presumably from coastal and riparian settings). Successional expansions of pioneer, deciduous and Mediterranean (deciduous and evergreen Quercus, Corylus and Olea), deciduous and heath (deciduous Quercus, Alnus 
and Ericaceae) and finally heath and steppe characterise all the interglacials (Roucoux et al., 2006). Glacial intervals are dominated by steppe taxa (Artemisia, Chenopodiaceae and Ephedra) with very low values of trees being detected. However, the rapid expansion of the latter during the interstadials of the last and penultimate glacial periods suggests that refugial populations of temperate trees survived in Portugal (Roucoux et al., 2001; Margari et al., 2014). In northwest Iberia the composite palynological record of all the available sequences (Desprat et al., 2017) reveals variations in the extent of temperate and humid forest communities of the last $450 \mathrm{ka}$. Although, broadly the same conclusions can be drawn in terms of vegetation responses and timings, there is a substantial difference in that all the interglacials are characterised by similar maxima in the arboreal pollen percentages, between 60 and $80 \%$. It has been suggested that since temperature is the main limiting factor controlling the expansion of trees in northwest Iberia (conditions being continuously sufficiently wet), similar temperatures were reached during every warm phase (Desprat et al., 2017). All glacial periods are dominated by steppe and arid-tolerant taxa.

\section{Synthesis}

During the Middle Pleistocene there are considerable regional differences in the vegetation structure and composition of southern Europe, depending on geographical and historical factors (Manzi et al., 2011). Arboreal populations expanded during warm and wet periods (interglacial/interstadials) and contracted during cold and dry intervals (glacials/stadials) on orbital timescales, as a response to astronomical forcing and ice volume changes. There is no strict, predictable relationship linking interglacial strength (as measured by arboreal pollen percentages) with either the strength of the insolation peak or the phasing between precession and obliquity.

Superimposed on the orbital variability, there is evidence for much shorter sub-orbital fluctuations. A substantial body of marine and terrestrial pollen evidence shows that millennial/centennial-scale instability has been a pervasive feature of the mode of change across southern Europe during glacial periods, with arboreal population size and composition changes associated with sea-surface temperature variations (Sánchez Goñi et al., 2000, 2016a; Roucoux et al., 2001, 2006, 2008, 2011; Margari et al., 2010, 2014; Fletcher et al., 2013). It has been recently suggested that the abandonment of inner Iberian territories by the Neanderthals around 42 ka was caused by deteriorating environmental conditions (Wolf et al., 2018). It is reasonable to assume that similar climatic oscillations occurring during the Middle Pleistocene, would have had a significant impact on hominin populations.

The duration of warm intervals is an important consideration when examining the climatic context for hominin evolution and dispersal, as not all interglacial intervals have the same duration. In the southwest Iberian Margin records show that MIS $11 \mathrm{c}$ is the longest interglacial spanning approximately 20 kyr followed by MIS 9c (15 kyr), MIS 19 (12 kyr) and finally MIS 7c (10.3 kyr) (Tzedakis et al., 2004b; Roucoux et al., 2006; Tzedakis, 2010; Sánchez Goñi et al., 2016b). Our understanding of climatic drivers and the patterns and timing of ecosystem responses across southern Europe provides a crucial framework for understanding hominin evolution and dispersal. For example, longer warm/forested intervals could have provided more time for spread 
into northern Europe, while cold/dry intervals may have restricted hominin populations to "refugial" areas in the south.

It has long been recognized that the continued local presence of temperate trees during glacial intervals meant that the Balkan, Italian and Iberian Peninsulas acted as longterm refugia. These areas were characterised by favourable climatic conditions and supported the prolonged presence of taxa, which were at the edge of their limits. The complexity in the timing of tree taxa extirpations in southern Europe has been recently highlighted by Magri et al. (2017). Especially in Italy, the geographical barriers of the Alps and the Mediterranean Sea might have favoured the local presence and isolation of both plant populations and mammals, including humans (Manzi et al., 2011). Indeed, there is evidence for periods of isolation of hominin populations in the morphological variability of $H$. heidelbergensis finds. It is possible that this isolation occurred in populations, which survived the extremes of the Pleistocene glacials in the temperate refugia of southern Europe, along with many other species (Stringer et al., 2012).

Finally, one of the greatest challenges remaining is the linking of archaeological evidence and palaeoclimatic records in time and space. The often-fragmentary nature of archaeological evidence, combined with uncertainties in absolute dating, impedes their precise correlation with lake or marine pollen records (Moncel et al., 2018). Moreover, there is a problem of spatial mismatch, as the local archaeological environment is not necessarily reflected in the more regional signal of palynological records. In order to understand the climatic and environmental context of hominin populations it would be ideal to have palaeoenvironmental evidence directly associated with the archaeological finds. However, even at Ceprano, where the archaeological evidence and the palaeoecological evidence are preserved in close proximity, the two kinds of evidence represent different periods of time. These spatial and temporal offsets are compounded by the fact that pollen grains are rarely preserved well or continuously with archaeological material (Carrión et al., 2009, 2011), making pollen analyses difficult to interpret and frustratingly inconclusive (e.g. Martinez et al., 2014). Fortunately, palaeoenvironmental reconstructions can also draw on alternative proxies that are better preserved with archaeological material such as the fossil remains of reptiles and amphibians (Blain et al., 2009, 2018) and large and small mammals (e.g. Rodriguez et al., 2011) in Atapuerca.

\section{Conclusions and implications for future research}

1) The palynological analysis of the Ceprano sequence reveals the existence of two forested phases prior to the deposition of the human calvarium. Based on biostratigraphical and sedimentological data these intervals have been assigned to MIS 13 , while the period of human occupation referred to the human calvarium has been ascribed to MIS 11.

2) The vegetation of MIS 13 at Ceprano was dominated by Corylus, Carpinus betulus, deciduous Quercus and Abies. Differences in the timing of extirpation of Tertiary taxa within geographically adjacent locations points to the importance of site specific factors, such as microclimate and topography, in determining the make-up of Pleistocene vegetation. This kind of spatial heterogeneity is an important component of the climatic and environmental context for hominin evolution, because it suggests that populations of hominins may be unlikely to have occupied entire regions at any given 
time, but instead are perhaps more likely to have targeted specific habitats with appropriate local conditions.

3) In general, the Middle Pleistocene was a time of pronounced oscillations in climate and in vegetation cover across southern Europe. The available records indicate some strong geographical patterns in palaeovegetation. In general there is an earlier extinction of exotic taxa in northern parts of our region (with some exceptions like Tsuga and Eucommia; see Magri et al., 2017). Present-day climatic contrasts between sites appear to be represented more or less consistently over time in the records (e.g. Ioannina is wetter than Tenaghi Philippon, southern France is cooler and wetter than the Mediterranean peninsulas). Geographical differences in climate are also reflected in the existence of refugial populations of temperate trees in more protected areas during glacial intervals. Although it appears that these refugia were a minor component of the regional landscape their existence and patterning in time and space could provide a useful starting point for future work on testing hypotheses about possible hominin refugia.

4) In terms of temporal patterns, the warmest periods of the Middle Pleistocene were short compared with the duration of glacial intervals. Within each interglacial, there is typically evidence for episodes of smaller amplitude and/or higher-frequency climatic change. Transitions from cold and dry to warm and wet intervals occurred on centennial timescales for glacial-to-interglacial oscillations and multi-decadal timescales for stadial-to-interstadial oscillations. Forest expansions were similarly rapid in southern Europe, almost keeping pace with climatic change, because of the proximity of refugial populations.

5) Every kind of palaeoecological record has its strengths (for example, the local signal provided by archaeological records; the stratigraphic completeness of marine and lake pollen records; the global and regional significance of marine isotope records), but it is important to recognise their limitations (for example, the often fragmentary nature and poor chronostratigraphic control of archaeological sites; the lack of local signal from large lake basins and marine pollen records; the fact that marine isotope records cannot be extrapolated to terrestrial environments directly, particularly in terms of the duration of climatic intervals). Despite the obvious challenges in reconciling the different kinds of records, we recommend closer collaboration between the palaeoecological/palaeoclimatological and archaeological communities. Combining the different kinds of records can help improve our understanding of what Pleistocene climatic change meant for hominin populations on the ground, while simultaneously providing the all-important context for detailed in situ palaeoenvironmental reconstructions from archaeological sites.

\section{Acknowledgements}

PCT and VM gratefully acknowledge support from The Leverhulme Trust through a research project grant $(\mathrm{F} / 00122 / \mathrm{AH})$ towards the palynological investigation of the Ceprano cores. Excavations 2001-2006 at Campogrande were directed by Itallo Biddittu and GM, authorized by the Soprintendenza Archeologica del Lazio and cofinanced by research grants from the SAPIENZA, University of Rome. Drillings at Campogrande were jointly financed and supervised by the Istituto per la Dinamica dei Processi Ambientali (CNR, Venice) and by the Istituto Italiano di Paleontologia Umana 
(Rome). We thank Giovanni Muttoni for sampling access to the cores. We are also grateful to Ian Lawson and two anonymous reviewers for comments on the manuscript, and to Rob Hosfield and James Cole for inviting KR and VM to participate in the workshop "Coping with climate: the legacy of Homo heidelbergensis" (February 2017), for stimulating thought-provoking discussions and for organizing the publication of this QSR issue.

\section{References}

- Amato, V., Aucelli, P.P.C., Cesarano, M., Jicha, B., Lebreton, V., Orain, R., Pappone, G., Petrosino, P., Russo Ermolli, E., 2014. Quaternary evolution of the largest intermontane basin of the Molise Apennine (central-southern Italy) Rend. Lincei 25, 197-216.

- Arzarello, M., Marcolini, F., Pavia, G., Pavia, M., Petronio, C., Petrucci, M., Rook, L., Sardella, R., 2007. Evidence of earliest human occurrence in Europe: the site of Pirro Nord (Southern Italy). Naturwissenschaften 94, 107-112.

- Ascenzi, A., Biddittu, I., Cassoli, P.F., Segre, A.G., Segre Naldini, E., 1996. A calvarium of late Homo erectus from Ceprano, Italy. J. Hum. Evol. 31, 409-423.

- Ascenzi, A., Segre, A.G., 1997. Resti di cranio umano del Pleistocene medioinferiore a Ceprano. Rend. Fis. Acc. Lincei 9, 39-67.

- Ascenzi, A., Mallegni, F., Manzi, G., Segre, A.G. \& Segre Naldini, E. 2000. A reappraisal of Ceprano calvaria affinities with Homo erectus, after the new reconstruction. J. Hum. Evol. 39, 443-450.

- Ashton, N., Lewis, S.G., 2012. The environmental contexts of early human occupation of northwest Europe: The British Lower Palaeolithic record. Quatern. Int. 271, 50-64.

- Attorre, F., Francesconi, F., Bartolucci, F., De Sanctis, M., Bruno, F., 2006. Flora analitica informatizzata della Zona di Protezione Speciale (ZPS) Monti SimbruiniErnici (Lazio Nord-Orientale) Inform. Bot. Ital. 38, 137-183.

- Bennett, K.D., 1993, 1998. PSIMPOLL. Available from: http://www.kv.geo.uu.se/ psimpoll.html.

- Bennett, K.D., Tzedakis, P.C. and Willis, K.J., 1991. Quaternary refugia of north European trees. J. Biogeogr. 18, 103-115.

- Berglund, B.E., Ralska-Jasiewiczowa, M., 1986. Pollen analysis and pollen diagrams. In: Berglund, B.E. (Ed.), Handbook of Holocene Palaeoecology and Palaeohydrology. Wiley, Chichester.

- Bertini, A., 2000. Pollen record from Colle Curti and Cesi: Early and Middle Pleistocene mammal sites in the UmbroeMarchean Apennine mountains (central Italy). J. Quat. Sci. 15, 825-840.

- Bertini, A., 2010. Pliocene to Pleistocene palynoflora and vegetation in Italy: state of the art. Quatern. Int. 225, 5-24.

- Bertini, A. Toti, F., Marino, M., Ciaranfi, N., 2015. Vegetation and climate across the Early-Middle Pleistocene transition at Montalbano Jonico, southern Italy. Quatern. Int. 383, 74-88.

- Blain, H.A., Bailon, S., Cuenca-Bescos, G., Arsuaga, J.L., de Castro, J.M.B., Carbonell, E., 2009. Long-term climate record inferred from early-middle Pleistocene amphibian and squamate reptile assemblages at the Gran Dolina Cave, Atapuerca, Spain. J. Hum. Evol. 56, 55-65. 
- $\quad$ Blain, H.-A., Cruz Silva, J.A., Jiménez Arenas, J.M., Margari, V., Roucoux, K., 2018. Towards a Middle Pleistocene terrestrial climate reconstruction based on herpetofaunal assemblages from the Iberian Peninsula: State of the art and perspectives. Quaternary Sci. Rev. 191, 167-188.

- Bruner, E. and Manzi, G., 2007. Landmark-Based Shape Analysis of the Archaic Homo Calvarium from Ceprano (Italy). Am. J. Phys. Anthropol. 132, 355-366.

- Capraro, L., Asioli, A., Backman, J., Bertoldi, R., Channell, J.E.T., Massari, F., Rio, D., 2005. Climatic Patterns Revealed by Pollen and Oxygen Isotope Records across the Matuyama-Brunhes Boundary in the Central Mediterranean (Southern Italy), vol. 247. Geol. Soc. Spec. Publ. 247, 159- 182.

- Carbonell, E., De Castro, J.M.B., Parés, J.M., Pérez-González, A., Cuenca-Bescós, G., Ollé, A., Mosquera, M., Huguet, R., Van Der Made, J., Rosas, A., Sala, R., 2008. The first hominin of Europe. Nature 452, 465-469.

- Carrión, J.S., Fernández, S., González-Sampériz, P., Leroy, S.A.G., López- Sáez, J.A., Burjachs, F., Gil-Romera, G., García-Antón, M., Gil-García, M.J., Parra, I., Santos, L., López-García, P., Yll, E.I., Dupré, M., 2009. Sterility cases and causes in Quaternary pollen analysis in the Iberian Peninsula: the advantages of reporting bad luck. Internet Archaeology, 25, 1-22.

- Carrión, J.S., Rose, J. and Stringer, C., 2011. Early human evolution in the western Palaearctic: ecological scenarios. Quaternary Sci. Rev. 30, 1281-1295.

- Centamore, E., Di Manna, P., Rossi, D., 2007. Kinematic evolution of the Volsci Range: A new overview. Boll. Soc. Geol. Ital. 126, 159-172.

- Clark, P.U., Archer, D., Pollard, D., Blum, J.D., Rial, J.A., Brovkin, V., Mix, A.C., Pisias, N.G., Roy, M., 2006. The middle Pleistocene transition: characteristics, mechanisms, and implications for long-term changes in atmospheric pCO 2 . Quaternary Sci. Rev. 25, 3150-3184.

- Combourieu-Nebout, N., Bertini, A., Russo-Ermolli, E., Peyron, O., Klotz, S., Montade, V., Fauquette, S., Allen, J., Fusco, F., Goring, S., Huntley, B., 2015. Climate changes in the central Mediterranean and Italian vegetation dynamics since the Pliocene. Rev. Palaeobot. Palynol. 218, 127-147.

- Corrado, P., Magri, D., 2011. A late Early Pleistocene pollen record from Fontana Ranuccio (central Italy). J. Quat. Sci. 26, 335-344.

- Degeai, J.-P., Pastre, J.-F., Gauthier, A., Robert, V., Nomade, S., Bout-Roumazeilles, V., Guillou, H., 2013. La sequence lacustre du maar d'Alleret (Massif Central, France): tephrochronologie et evolution paleoenvironnementale en Europe occidentale au debut du Pleistocene moyen. Quaternaire 24, 443- 459.

- Dennell, R.W., Martinón-Torres, M., de Castro, J.M.B., 2011. Hominin variability, climatic instability and population demography in Middle Pleistocene Europe. Quaternary Sci. Rev. 30, 1511-1524.

- Desprat, S., Oliveira, D., Naughton, F, Sanchez Goni, M.F., 2017. L'étude du pollen des séquences sédimentaires marines pour la compréhension du climat : l'exemple des périodes chaudes passes. Quaternaire 28, 259-269.

- De Sillo, R., De Sanctis, M., Bruno, F., Attorre, F., 2012. Vegetation and landscape of the Simbruini mountains (Central Apennines). Plant Sociology 49, 3-64.

- Di Pietro, R., Blasi, C., 1997. Gli ostrieti mesofili dei Monti Ausoni (Lazio Meridionale). Arch. Geobot. 3, 19-39.

- Di Vincenzo, F., Profico, A., Bernardini, F., Cerroni, V., Dreossi, D., Schlager, S., Zaio, P., Benazzi, S., Biddittu, I., Rubini, M., Tuniz, C., Manzi, G., 2017. Digital 
reconstruction of the Ceprano calvarium (Italy), and implications for its interpretation. Sci. Rep -UK 7, art. no. 13974

- EPICA Community Members, 2004. Eight glacial cycles from an Antarctic ice core. Nature 429, 623-628.

- Fletcher, W.J., Goni, M.F.S., Allen, J.R., Cheddadi, R., Combourieu-Nebout, N., Huntley, B., Lawson, I., Londeix, L., Magri, D., Margari, V., Müller, U.C., 2010. Millennial-scale variability during the last glacial in vegetation records from Europe. Quaternary Sci. Rev. 29, 2839-2864.

- Follieri, M., Magri, D., Sadori, L., 1988. 250000-year pollen record from Valle di Castiglione (Roma). Pollen Spores 30, 329-356.

- Follieri, M., Magri, D., Sadori, L., 1989. Pollen stratigraphical synthesis from Valle di Castiglione (Roma). Quatern. Int. 3, 81-84.

- Fusco, F., 2007. Vegetation response to early Pleistocene climatic cycles in the Lamone valley (Northern Apennines, Italy). Rev. Palaeobot. Palynol. 145, 1-23.

- García-Antón, M., Sainz-Ollero, H., 1991. Pollen records from the middle Pleistocene Atapuerca site (Burgos, Spain). Palaeogeog. Palaeoecl 85, 199-206.

- González-Sampériz, P., Leroy, S.A.G., Carricn, J.S., Fernández, S., García-Anton, M., Gil-García, M.J., Uzquiano, P., Valero-Garcés, B., 2010. Figueiral, I. Steppes, savannahs, forests and phytodiversity reservoirs during the Pleistocene in the Iberian Peninsula. Rev. Palaeobot. Palynol. 162, 427-457.

- Head, M.J., Gibbard, P.L., 2015. Early-Middle Pleistocene transitions: linking terrestrial and marine realms. Quatern. Int. 389, 7-46.

- Heuzé, P., Dupouey, J.-L., Schnitzler, A., 2009. Radial growth response of Hedera helix to hydrological changes and climatic variability in the Rhine floodplain. River Res. Appl. 25, 393-404.

- Hewitt, G., 2000. The genetic legacy of the Quaternary ice ages. Nature 405, 907 913.

- Hublin, J.-J. 2009. The origin of Neandertals. P. Natl. Acad. Sci. USA 106, 16022 16027.

- Iversen, J., 1944. Viscum, Hedera and Ilex as Climate Indicators. GFF 66, 463-483.

- Joannin, S., Quillevere, F., Suc, J.-P., Lecuyer, C., Martineau, F., 2007. Early Pleistocene climate changes in the central Mediterranean region as inferred from integrated pollen and planktonic foraminiferal stable isotope analyses. Quaternary Res. 67, 264-274.

- Kousis, I., Koutsodendris, A., Peyron, O., Leicher, N., Francke, A., Wagner, B., Giaccio, B., Knipping, M., Pross, J., 2018. Centennial-scale vegetation dynamics and climate variability in SE Europe during Marine Isotope Stage 11 based on a pollen record from Lake Ohrid. Quaternary Sci. Rev. 190, 20-38.

- Lang, N., Wolff, E.W., 2011. Interglacial and glacial variability from the last 800 ka in marine, ice and terrestrial archives. Clim. Past 7, 361-380.

- Lawson, I., Frogley, M., Bryant, C., Preece, R., Tzedakis, P., 2004. The Lateglacial and Holocene environmental history of the Ioannina basin, north-west Greece. Quaternary Sci. Rev. 23, 1599-1625.

- Lebreton, V., 2002. Vegetation et climat au Pleistocene inferieur et moyen a La Pineta (Isernia, Italie). Comptes Rendus Palevol. 1, 11-17.

- Magri, D., 1999. Late Quaternary vegetation history at Lagaccione near Lago di Bolsena (central Italy). Rev. Palaeobot. Palynol. 106, 171-208. 
- Magri, D., 2010. Persistence of tree taxa in Europe and Quaternary climate changes. Quatern. Int. 219, 145-151.

- $\quad$ Magri, D., Agrillo, E., Di Rita, F., Furlanetto, G., Pini, R., Ravazzi, C., Spada, F., 2015. Holocene dynamics of tree taxa populations in Italy Rev. Palaeobot. Palynol. 218, 267-284.

- Magri, D., Di Rita, F., Aranbarri, J., Fletcher, W., González-Sampériz, P. 2017. Quaternary disappearance of tree taxa from Southern Europe: Timing and Trends. Quaternary Sci. Rev. 163, 23-55.

- Magri, D., Palombo, M.R., 2013. Early to Middle Pleistocene dynamics of plant and mammal communities in South West Europe. Quatern. Int. 288, 63-72.

- Manzi, G., 2016. Humans of the Middle Pleistocene: The controversial calvarium from Ceprano (Italy) and its significance for the origin and variability of Homo heidelbergensis. Quatern. Int. 411, 254-261.

- Manzi, G., Magri, D., Milli, S., Palombo, M.R., Margari, V., Celiberti, V., Barbieri, M., Barbieri, M., Melis, R.T., Rubini, M., Ruffo, M., 2010. The new chronology of the Ceprano calvarium (Italy). J. Hum. Evol 59, 580-585.

- Manzi, G., Magri, D., Palombo, M.R., 2011. Early-Middle Pleistocene environmental changes and human evolution in the Italian peninsula. Quaternary Sci. Rev. 30, 1420-1438.

- Margari, V., Skinner, L.C., Tzedakis, P.C., Ganopolski, A., Vautravers, M., Shackleton, N.J., 2010. The nature of millennial-scale climate variability during the past two glacial periods. Nat. Geosci. 3, 127-131.

- Margari, V., Skinner, L.C., Hodell, D.A., Martrat, B., Toucanne, S., Grimalt, J.O., Gibbard, P.L., Lunkka, J.P., Tzedakis, P.C., 2014. Land-ocean changes on orbital and millennial time scales and the penultimate glaciation. Geology 42, 183-186.

- Martínez- Navarro, B., Turq, A., Ballester, J. A., Oms, O., 1997. Fuente Nueva-3 (Orce, Granada, Spain) and the first human occupation of Europe. J. Hum. Ev. 33, 611-620.

- $\quad$ Metcalfe, D.J., 2005. Hedera helix L. J. Ecol. 93, 632-648.

- Mommersteeg, H.J.P.M., Loutre, M.F., Young, R., Wijmstra, T.A., Hooghiemstra, H., 1995. Orbital forced frequencies in the 975000 year pollen record from Tenagi Philippon (Greece). Clim. Dynam. 11, 4-24.

- Moncel, M-H., Schreve, D., 2016. The Acheulean in Europe: Origins, evolution and dispersal. Quatern. Int. 411, 1-8.

- Moncel, M-H., Landais, A., Lebreton, V., Combourieu-Nebout, N., Nomade, S. Bazin, L., 2018. Linking environmental changes with human occupations between 900 and 400 ka in Western Europe. Quatern. Int. 480, 78-94.

- Moore, P.D., Webb, J.A., Collinson, M.E., 1991. Pollen Analysis, second ed. Blackwell Scientific Publications, Oxford.

- Munno, R., Petrosino, P., Romano, P., Russo Ermolli, E., Juvigné, E., 2001. A late Middle Pleistocene climatic cycle in southern Italy inferred from pollen analysis and tephrostratigraphy of the Acerno lacustrine succession. Géog. Phys. Quatern. 55, 87-99.

- Muttoni, G., Carcano, C., Garzanti, E., Ghielmi, M., Piccin, A., Pini, R., Rogledi, S., Sciunnach, D., 2003. Onset of major Pleistocene glaciations in the Alps. Geology 31, 989-992. 
- Muttoni, G., Scardia, G., Kent, D.V., Swisher, C.C., Manzi, G., 2009. Pleistocene magnetochronology of early hominin sites at Ceprano and Fontana Ranuccio, Italy. Earth Planet. Sci. Lett. 286, 255-268.

- $\quad$ Nomade, S., Gauthier, A., Guillou, H., Pastre, J.-F., 2010. ${ }^{40} \mathrm{Ar} /{ }^{39} \mathrm{Ar}$ temporal framework for the Alleret maar lacustrine sequence (French Massif-Central): Volcanological and paleoclimatic implications. Quat. Geochronol. 5, 20-27.

- Nomade, S., Muttoni, G., Guillou, H., Robin, E., Scardia, G., 2011. First ${ }^{40} \mathrm{Ar} /{ }^{39} \mathrm{Ar}$ age of the Ceprano man (central Italy). Quat. Geochronol. 6, 453-457.

- Oms, O., Parés, J.M., Martínez-Navarro, B., Agustí, J., Toro, I., Martínez-Fernández, G., Turq, A., 2000. Early human occupation of Western Europe: paleomagnetic dates for two paleolithic sites in Spain. P. Natl. Acad. Sci. USA 97, 10666-10670.

- Orain, R., Lebreton, V., Ermolli, E.R., Aucelli, P., Amato, V., 2012. Végétation et climat au pléistocéne moyen en italie Méridionale (Bassin de boiano, Molise). Quaternaire 23, 37-48.

- Orain, R., Lebreton, V., Ermolli, E.R., Combourieu-Nebout, N., Sémah, A.-M., 2013. Carya as marker for tree refuges in southern Italy (Boiano basin) at the Middle Pleistocene. Palaeogeogr. Palaeoecl. 369, 295-302.

- Palombo, M.R., Raia, P., Giovinazzo, C., 2005. Early-Middle Pleistocene structural changes in mammalian communities from the Italian peninsula. Geol. Soc. Spec. Publ. 247, 251-262.

- Palombo, M.R., Valli, A.M., 2005. Highlighting the Early-Middle Pleistocene transition in Italian and French large-mammal faunas: similarities and faunal renewals. Geol. Soc. Spec. Publ. 247, 263-276.

- Past Interglacials Working Group of PAGES, 2016. Interglacials of the last 800,000 years. Rev. Geophys. 54, 162-219.

- Pastre, J.-F., Gauthier, A., Nomade, S., Orth, P., Andrieu, A., Goupille, F., Guillou, H., Kunesch, S., Scaillet, S., Renne, P.R., 2007. The Alleret maar (Massif Central, France): a new lacustrine sequence of the early Middle Pleistocene in western Europe. Comptes Rendus Geosci. 339, 987-997.

- Pieruccini, P., Di Celma, C., Di Rita, F., Magri, D., Carnevale, G., Farabollini, P., Ragaini, L., Caffau, M., 2016. Sedimentology, faunal content and pollen record of Middle Pleistocene palustrine and lagoonal sediments from the Peri-Adriatic basin (Abruzzi, eastern central Italy). Quaternary Res. 86, 359-372.

- Pini, R., Ravazzi, C., Donegana, M., 2009. Pollen stratigraphy, vegetation and climate history of the last $215 \mathrm{ka}$ in the Azzano Decimo core (plain of Friuli, north-eastern Italy) Quaternary Sci. Rev. 28, 1268-1290.

- Petrosino, P., Jicha, B., Mazzeo, F.C., Russo Ermolli, E., 2014a. A high resolution tephrochronological record of MIS 14-12 in the Southern Apennines (Acerno Basin, Italy). J. Volcanol. Geotherm. Res. 274, 34-50.

- Petrosino, P., Russo Ermolli, E., Donato, P., Jicha, B., Robustelli, G., Sardella, R., 2014b. Using tephrochronology and palynology to date the MIS13 lacustrine sediments of the Mercure basin (Southern Apennines, Italy). Ital. J. Geosci. 133, 169-186.

- $\quad$ Ravazzi, C., Pini, R., Breda, M., Martinetto, E., Muttoni, G., Chiesa, S., Confortini, F., Egli, R., 2005. The lacustrine deposits of Fornaci di Ranica (late Early Pleistocene, Italian Pre-Alps): Stratigraphy, palaeoenvironment and geological evolution. Quatern. Int. 131, 35-58. 
- Ravazzi, C. (Ed.), 2003. Gli antichi bacini lacustri e i fossili di Leffe, Ranica e Pianico- Sellere (Prealpi Lombarde). CNR Consiglio Nazionale delle Ricerche, Istituto per la dinamica dei processi ambientali.

- Reille, M., 1992. Pollen et spores d' Europe et D' Afrique. Laboratoire de Botanique Historique et Palynologie, Marseille.

- Reille, M., de Beaulieu, J.L., 1995. Long Pleistocene pollen records from the Praclaux Crater, south-central France. Quaternary Res. 44, 205-215.

- $\quad$ Reille, M., Andrieu, V., de Beaulieu, J.L., Guenet, P., Goeury, C., 1998. A long pollen record from Lac du Bouchet, Massif Central, France: for the period ca. 325 to 100 ka BP (OIS 9c to OIS 5e). Quaternary Sci. Rev. 17, 1107-1123.

- Reille, M., Beaulieu, J.D., Svobodova, H., Andrieu-Ponel, V., Goeury, C., 2000. Pollen analytical biostratigraphy of the last five climatic cycles from a long continental sequence from the Velay region (Massif Central, France). J. Quat. Sci. 15, 665-685.

- Rightmire, G.P., 1998. Human Evolution in the Middle Pleistocene: The Role of Homo heidelbergensis. Evol. Anthr. 6, 218-227.

- Rodríguez, J., Burjachs, F., Cuenca-Bescós, G., García, N., Van der Made, J., Pérez González, A., Blain, H.-A., Expósito, I., López-García, J.M., García Antón, M., Allué, E., Cáceres, I., Huguet, R., Mosquera, M., Ollé, A., Rosell, J., Parés, J.M., Rodríguez, X.P., Díez, C., Rofes, J., Sala, R., Saladié, P., Vallverdú, J., Bennasar, M.L., Blasco, R., Bermúdez de Castro, J.M., Carbonell, E., 2011. One million years of cultural evolution in a stable environment at Atapuerca (Burgos, Spain) Quaternary Sci. Rev. 30, 1396-1412.

- Roucoux, K.H., Shackleton, N.J., de Abreu, L., Schönfeld, J., Tzedakis, P.C., 2001. Combined marine proxy and pollen analyses reveal rapid Iberian vegetation response to North Atlantic millennial-scale climate oscillations. Quaternary Res. $56,128-132$.

- Roucoux, K.H., Tzedakis, P.C., de Abreu, L., Shackleton, N.J., 2006. Climate and vegetation changes 180,000 to 345,000 years ago recorded in a deep-sea core off Portugal. Earth Planet. Sci. Lett. 249, 307-325.

- Roucoux, K.H., Tzedakis, P.C., Frogley, M.R., Lawson, I.T., Preece, R.C., 2008. Vegetation history of the marine isotope stage 7 interglacial complex at Ioannina, NW Greece. Quaternary Sci. Rev. 27,1378-1395.

- Roucoux, K.H., Tzedakis, P.C., Lawson, I.T. and Margari, V., 2011. Vegetation history of the penultimate glacial period (Marine isotope stage 6) at Ioannina, north-west Greece. J. Quaternary Sci. 26, 616-626.

- Russo Ermolli, E., 1994. Analyse pollinique de la succession lacustre pleistocene du Vallo di Diano (Campanie, Italie). Ann. la Societe geologique Belg. 117, 333354.

- Russo Ermolli, E., 2000. Pollen analysis of the Acerno palaeolacustrine succession (Middle Pleistocene, southern Italy). M.B. Hart (Ed.), Climates: Past and Present, Geological Society, London, Special Publication, 181, 151-159.

- Russo Ermolli, E.R., Cheddadi, R., 1997. Climatic reconstruction during the Middle Pleistocene: a pollen record from Vallo di Diano (Southern Italy). Geobios -Lyon 30, 735-744.

- Russo Ermolli, E., Aucelli, P.P.C., Di Rollo, A., Mattei, M., Petrosino, P., Porreca, M., Rosskopf, C.M., 2010. An integrated stratigraphical approach to the Middle 
Pleistocene succession of the Sessano basin (Molise, Italy). Quatern. Int. 225, 114-127.

- Russo Ermolli, E., Di Donato, V., Martín-Fern_andez, J.A., Orain, R., Lebreton, V., Piovesan, G., 2015. Vegetation patterns in the Southern Apennines (Italy) during MIS 13: deciphering pollen variability along a NW-SE transect. Rev. Palaeobot. Palynol. 218, 167-183.

- Sadori, L., Koutsodendris, A., Panagiotopoulos, K., Masi, A., Bertini, A., Combourieu-Nebout, N., Francke, A., Kouli, K., Joannin, S., Mercuri, A.M., Peyron, O., Torri, P., Wagner, B., Zanchetta, G., Sinopoli, G., Donders, T.H., 2016. Pollenbased paleoenvironmental and paleoclimatic change at Lake Ohrid (southeastern Europe) during the past $500 \mathrm{ka}$. Biogeosciences 13, 1423-1437.

- Sánchez Goñi, M.F., Turon, J.-L., Eynaud, F., Gendreau, S., 2000. European climatic response to millenial-scale changes in the atmosphere-ocean system during the Last Glacial period. Quaternary Res 54, 394-403.

- Sánchez Goñi, M. F., Llave, E., Oliveira, D., Naughton, F., Desprat, S., Ducassou, E., Hodell, D.A., Hernández-Molina, F.J., 2016a. Climate changes in south western Iberia and Mediterranean Outflow variations during two contrasting cycles of the last 1Myrs: MIS 31-MIS 30 and MIS 12-MIS 11. Global Planet. Change 136, 18-29.

- Sánchez Goñi, M. F., Rodrigues, T., Hodell, D.A., Polanco-Martinez, J.M., AlonsoGarcía, M., Hernández-Almeida, I., Desprat, S., Ferretti, P., 2016b. Tropicallydriven climate shifts in southwestern Europe during MIS 19, a low eccentricity interglacial. Earth Planet. Sc. Lett. 448, 81-93.

- Segre, A.G., Biddittu, I., 2009. Pléistocène moyen et inférieur dans le Latium (Italie centrale). L'Anthropologie 113, 59-65.

- Spratt, R.M., Lisiecki, L.E., 2016. A Late Pleistocene sea level stack. Clim. Past 12, 1079-1092.

- Stockmarr, J., 1971. Tablets with spores used in absolute pollen analysis. Pollen Spores 13, 615-621.

- Stringer, 2012. C. The status of Homo heidelbergensis (Schoetensack 1908). Evol. Anthr. 21, 101-107.

- Toro-Moyano, I., Martínez-Navarro, B., Agustí, J., Souday, C., de Castro, J.M.B., Martinón-Torres, M., Fajardo, B., Duval, M., Falguères, C., Oms, O., Parés, J.M., 2013. The oldest human fossil in Europe, from Orce (Spain). J. Hum. Ev. 65, 1-9.

- Tutin, T.G., Heywood, V.H., Moore, D.M., Valentine, D.H., Walters, S.M., Webb, D.A., 1964-1980. Flora Europaea, 5 Volumes. Cambridge University Press, Cambridge.

- Tzedakis, P.C., 2007. Seven ambiguities in the Mediterranean palaeoenvironmental narrative. Quaternary Sci. Rev. 26, 2042-2066.

- Tzedakis, P.C., 2010. The MIS 11-MIS 1 analogy, southern European vegetation, atmospheric methane and the" early anthropogenic hypothesis". Clim. Past 6, 131-144.

- Tzedakis, P.C., Andrieu, V., De Beaulieu, J.L., Crowhurst, S.D., Follieri, M., Hooghiemstra, H., Magri, D., Reille, M., Sadori, L., Shackleton, N.J., Wijmstra, T.A., 1997. Comparison of terrestrial and marine records of changing climate of the last 500,000 years. Earth Planet. Sc. Lett. 150, 171-176. 
- Tzedakis, P.C., Lawson, I.T., Frogley, M.R., Hewitt, G.M., Preece, R.C., 2002. Buffered tree population changes in a Quaternary refugium: evolutionary implications. Science 297, 2044-2047.

- $\quad$ Tzedakis, P.C., Frogley, M.R., Heaton, T.H.E., 2003. Last Interglacial conditions in southern Europe: evidence from Ioannina, northwest Greece. Global Planet. Change 36, 157-170.

- Tzedakis, P.C., Frogley, M.R., Lawson, I.T., Preece, R.C., Cacho, I., De Abreu, L., 2004a. Ecological thresholds and patterns of millennial-scale climate variability: the response of vegetation in Greece during the last glacial period. Geology 32, 109-112.

- $\quad$ Tzedakis, P.C., Roucoux, K.H., De Abreu, L., Shackleton, N.J., 2004b. The duration of forest stages in southern Europe and interglacial climate variability. Science 306, 2231-2235.

- Tzedakis, P.C., Hooghiemstra, H., Palike, H., 2006. The last 1.35 million years at Tenaghi Philippon: revised chronostratigraphy and long-term vegetation trends. Quaternary Sci. Rev. 25, 3416-3430.

- $\quad$ Tzedakis, P.C., Raynaud, D., McManus, J.F., Berger, A., Brovkin, V., Kiefer, T., 2009. Interglacial diversity. Nat. Geosci. 2, 751-755.

- Tzedakis, P.C., Emerson, B.C., Hewitt, G.M., 2013. Cryptic or mystic? Glacial tree refugia in northern Europe. Trends Ecol. Evol. 28, 696-704.

- Van der Wiel, A., Wijmstra, T., 1987a. Palynology of the 112.8e197.8 m interval of the core Tenaghi Philippon III, Middle Pleistocene of Macedonia. Rev. Palaeobot. Palynol. 52, 89-117.

- Van der Wiel, A., Wijmstra, T., 1987b. Palynology of the lower part (78e120 m) of the core Tenaghi Philippon II, Middle Pleistocene of Macedonia, Greece. Rev. Palaeobot. Palynol. 52, 73-88.

- Watts, W.A., Allen, J.R.M., Huntley, B., Fritz, S.C., 1996. Vegetation history and climate of the last 15,000 years at Laghi di Monticchio, southern Italy. Quaternary Sci. Rev. 15, 113-132.

- Wijmstra, T., 1969. Palynology of the first 30 metres of a $120 \mathrm{~m}$ deep section in northern Greece. Acta Bot. Neerl. 18, 511-527.

- Wijmstra, T.A. and Smit, A., 1976. Palynology of the middle part (30-78 metres) of the 120 m deep section in northern Greece (Macedonia). Plant Biol. 25, 297312.

- Wijmstra, T.A., Young, R., Witte, H.J.L., 1990. An evaluation of the climatic conditions during the Late Quaternary in northern Greece by means of multivariate analysis of palynological data and comparison with recent phytosociological and climatic data. Geologie en Mijnbouw, 69, 243-251.

- Wolf, D., Kolb, T., Alcaraz-Castaño, M., Heinrich, S., Baumgart, P., Calvo, R., Sánchez, J., Ryborz, K., Schäfer, I., Bliedtner, M., Zech, R., Zöller, L., Faust, D., 2018. Climate deteriorations and Neanderthal demise in interior Iberia. Sci. Rep. 8, art. no. 7048.

\section{Figure captions}

Figure 1: Map showing the location of the palynological sequences and key archaeological sites mentioned in the text. Tenaghi Philippon (Wijmstra and Smit, 
1976; Van der Wiel and Wijmstra, 1987a, b; Tzedakis et al., 2006), Ioannina (Tzedakis et al., 2002, 2003, 2004; Lawson et al., 2004; Roucoux et al., 2008, 2011), Ohrid (Sadori et al., 2016; Kousis et al., 2018), Sessano (Russo Ermolli et al., 2010, 2015), Boiano (Orain et al., 2012, 2013; Amato et al., 2014), Acerno (Russo Ermolli, 2000; Munno et al., 2001; Petrosino et al., 2014a), Vallo di Diano (Russo Ermolli 1996; Russo Ermolli and Cheddadi, 1997), Mercure (Petrosino et al., 2014b), Valle di Castiglione (Follieri et al., 1988, 1989), Velay: Praclaux (Reille and de Beaulieu, 1995) and Lac du Bouchet (Reille et al., 1998), Alleret (Pastre et al., 2007; Nomade et al., 2010; Degeai et al., 2013), Atapuerca (García-Antón and Sainz-Ollero, 1991), MD01-2443 (Tzedakis et al., 2004; Roucoux et al., 2006; Tzedakis, 2010), MD01-2444 (Margari et al., 2010, 2014), U1385 (Sánchez Goñi et al., 2016a, b), MD01-2447 (Desprat et al., 2005, 2006) and MD01-2697 (Desprat et al., 2009).

Figure 2: Top panel: Location of Campogrande in the Italian peninsula and enlarged view of southern Latium, The position of the Campogrande area is shown relative to the town of Ceprano and other localities of the Latina Valley mentioned in the text. The shadowed area corresponds to the inferred maximum extension of the Lirino Lake during the Pleistocene. Lower panel: Topographical map (a) and schematic section (b) of the area of Campogrande, where 2001-2006 field activities were carried out. Relative position of Core 1 (C1) and Core 2 (C2), discovery site of the human calvarium $(\mathrm{H})$, excavated stratigraphic witness above the present ground level (W), trench downwards the slope towards the Fosso della Manoviccia (T), site of excavation of a rather complete skeleton of Palaeoloxodon antiquus (P). An oblique view of the Ceprano human calvarium is also shown. After Manzi et al. (2010).

Figure 3: Sediment composition and concentration of selected pollen taxa for the C1 Ceprano sequence. The star marks the deposition level of the Ceprano human calvarium.

Figure 4: Selected pollen taxa percentages against depth $(\mathrm{m})$ for the $\mathrm{C} 1$ sequence. The total pollen sum used for the calculation of pollen percentages excluded obligate aquatics, spores and Cyperaceae (which were individually added to the main sum in order to calculate their percentages)

Figure 5: Summary pollen records from lacustrine and marine records in southern Europe spanning the Middle Pleistocene: Tenaghi Philippon (Tzedakis et al., 2006), Ioannina (Roucoux et al., 2007, 2011), Valle di Castiglione (Follieri et al., 1988), the Velay maars (Lac du Bouchet and Praclaux; Reille et al., 2000). Data are shown as percentages of the total land pollen, against age (ka). In the terrestrial sequences, percentage arboreal pollen (AP) is shown in grey, and arboreal pollen excluding pioneer and cold-tolerant taxa (Pinus, in the case of the Valle di Castiglione and Velay Maar records, and Pinus, Juniperus and Betula in the case of Tenaghi Philippon and Ioannina) is shown in black. In the marine record, the curve represents the percentage of arboreal taxa excluding pioneer and Mediterranean taxa; the data from MD01-2443 are shown in black and the data from MD01-2444 are shown in grey (Tzedakis et al., 2004; Roucoux et al., 2006; Margari et al., 2014). The summary pollen record from Ceprano is plotted against depth with AP \% drawn in black and AP minus Pinus, Juniperus and Betula in grey; dotted lines indicate the proposed correlation with the Tenaghi Philippon record 
Author accepted manuscript. May contain errors subsequently corrected at proof stage. Please contact K. Roucoux (khr@st-andrews.ac.uk) for more information about this work.

and the marine isotope straigraphic equivalents (indicated at the top of the figure, following Tzedakis et al. 2006). 


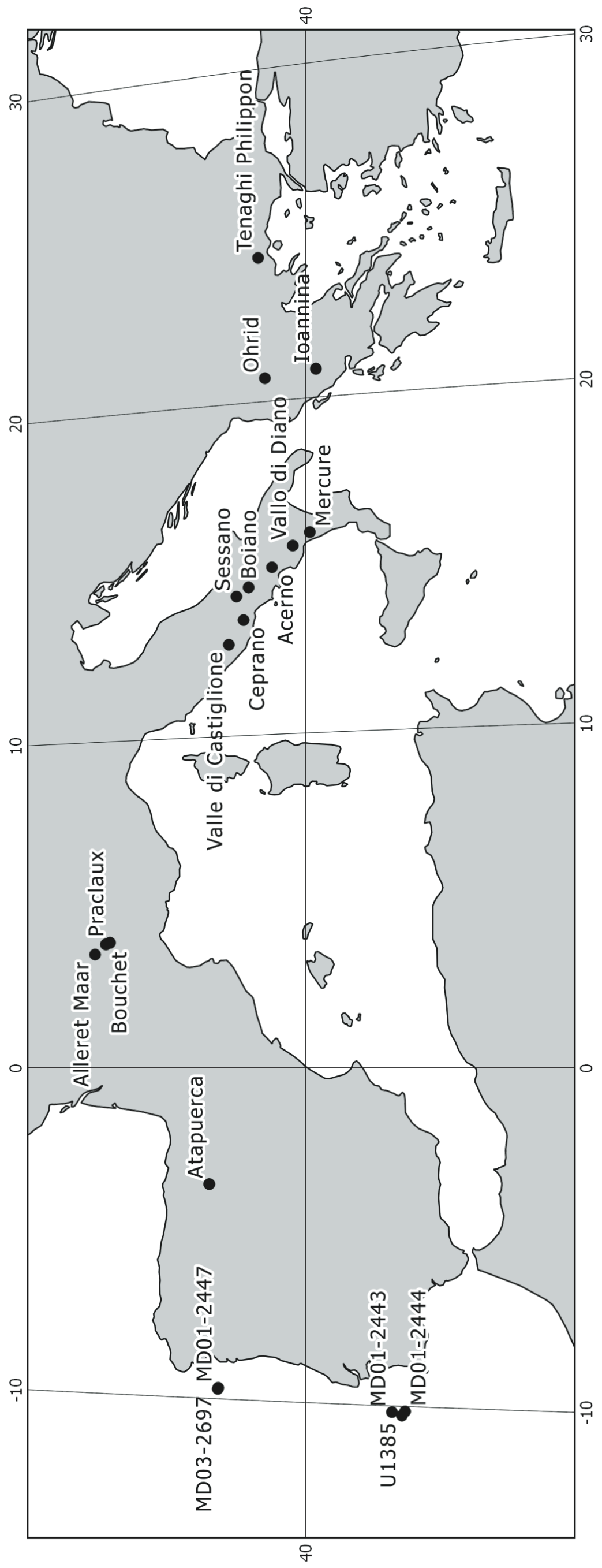



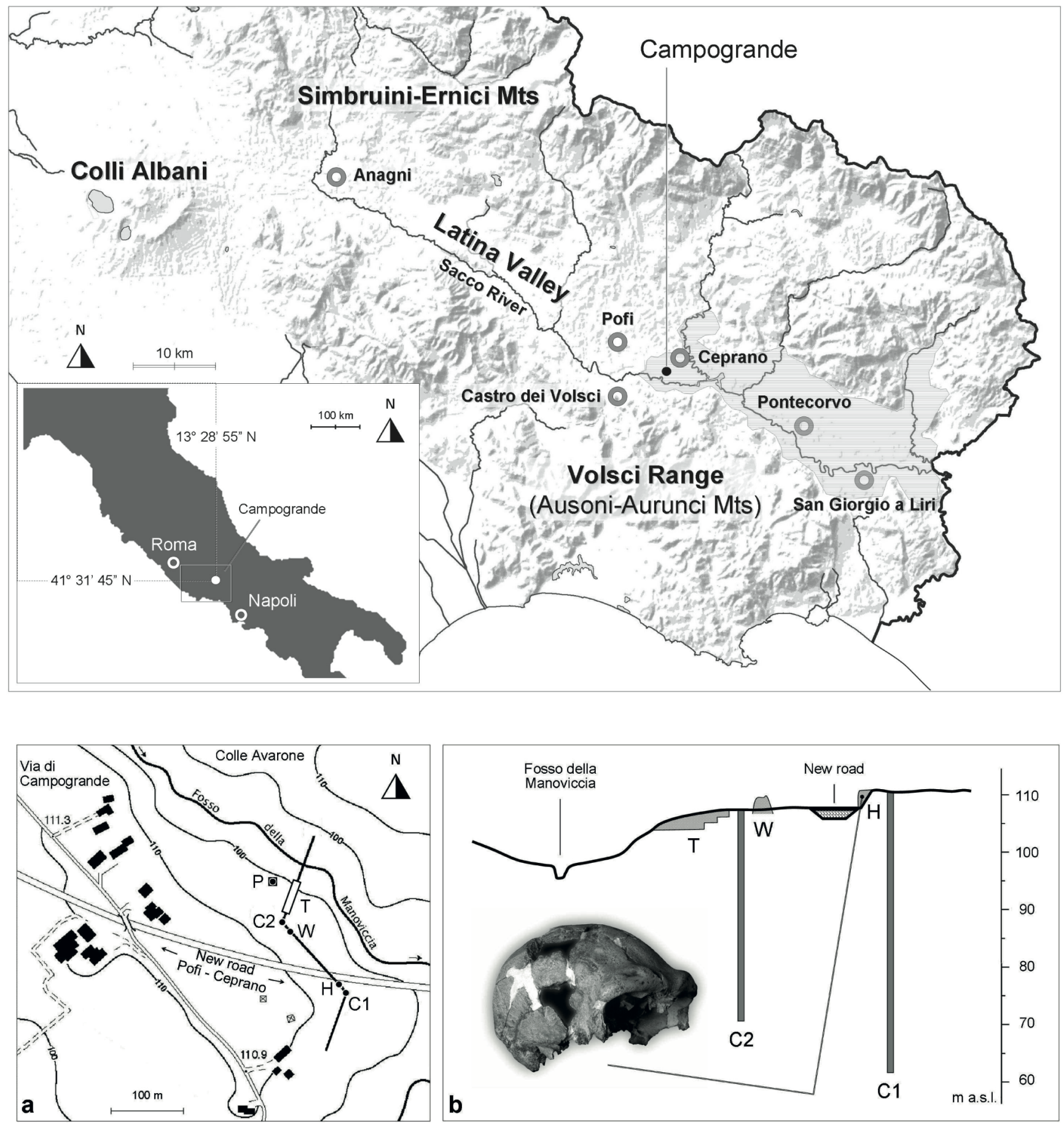


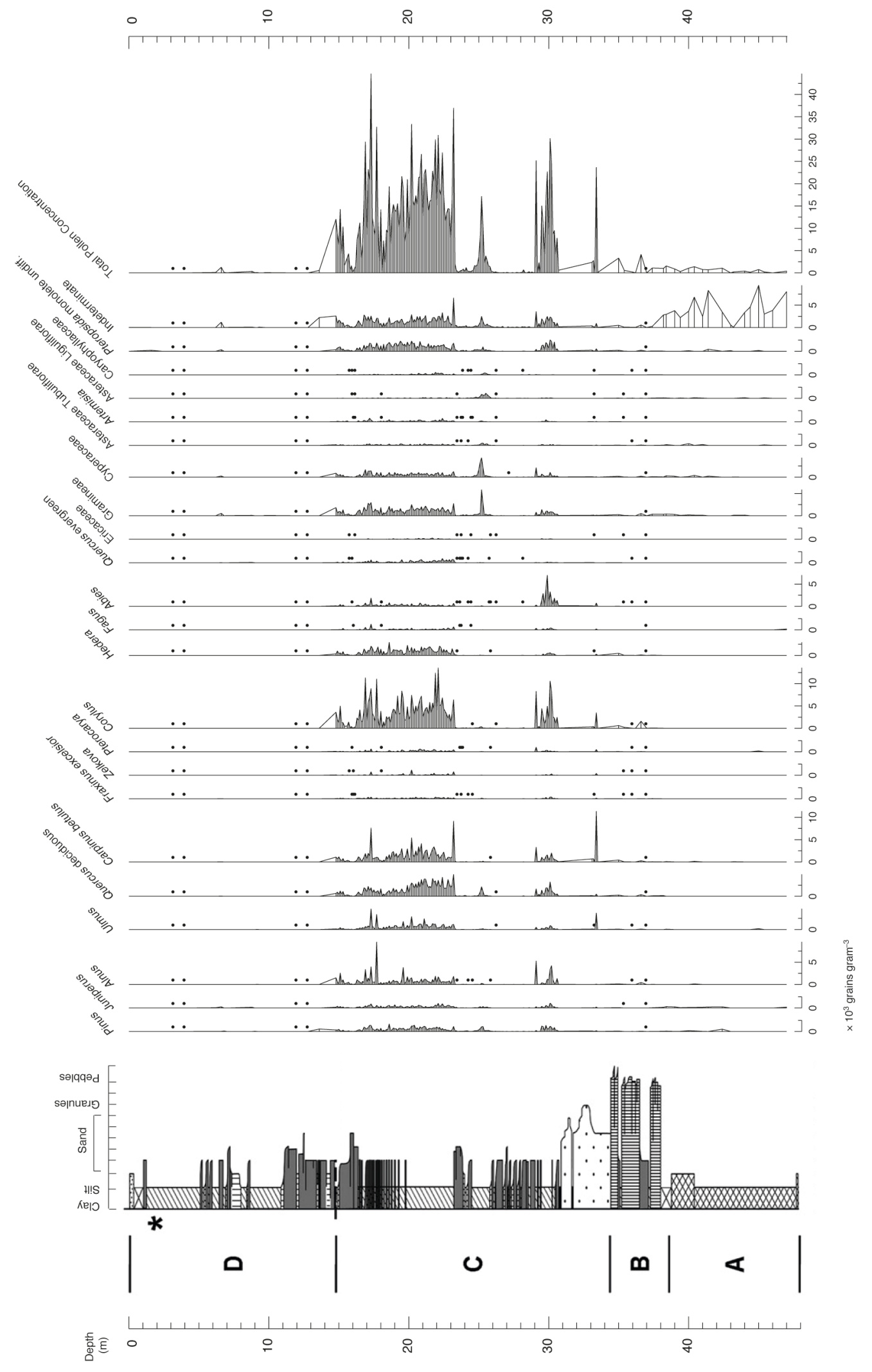




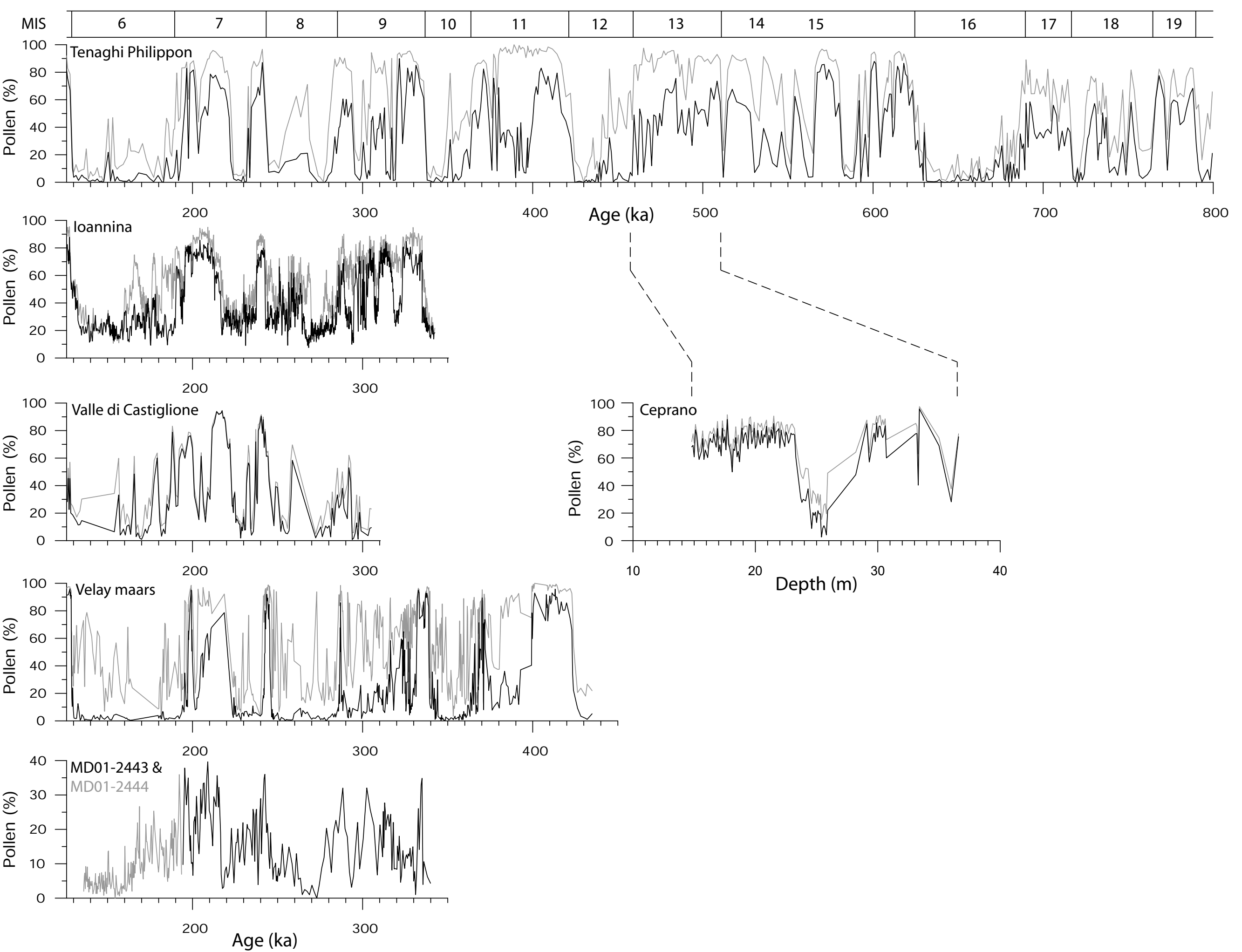

